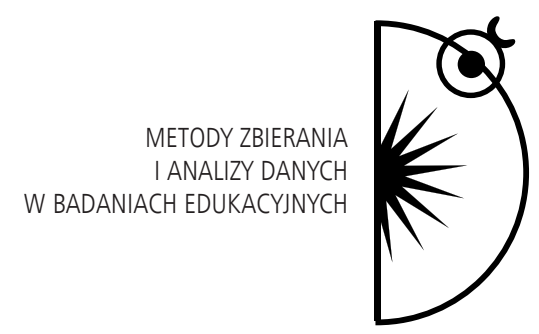

Władysława Szulakiewicz

\title{
Ego-dokumenty $i$ ich znaczenie w badaniach naukowych
}

DOI: http://dx.doi.org/10.12775/PBE.2013.006

\section{Uwagi wstępne}

Łatwo dostrzec, że we współczesnych badaniach naukowych znacznie wzrosło zainteresowaniem tzw. historią osobistą ${ }^{1}$. Ta orientacja badawcza, ukazująca znaczenie ego-dokumentów, ma licznych zwolenników wśród przedstawicieli wielu dyscyplin naukowych, a w szczególności historii, historii literatury, socjologii. Bowiem dzięki ego-dokumentom, jak słusznie mówi niemiecki uczony W. Schulze, jesteśmy bliżej ludzi w historii ${ }^{2}$. Dzięki ego-dokumentom mamy niejako bardziej bezpośredni dostęp do wydarzeń historycznych. W pi-

\footnotetext{
Artykuł nie pretenduje do miana tekstu wyczerpującego podjęte zagadnienie. Jedynym jego celem jest zasygnalizowania ważności ego-dokumentów w badaniach naukowych. W artykule odwołuję się, do niektórych ustaleń zawartych w moich opublikowanych tekstach, m.in. są to: Pamiętnikarski portret nauczycieli w ujęciu Rafała Taubenschlaga (1881-1958), w: Z dziejów polskiej oświaty. Księga Jubileuszowa dedykowana Profesor Danucie Koźmian, red. I. Kość i E. Magiera, Szczecin 2007, s. 85-95; Rola literatury pamiętnikarskiej w rekonstrukcji obrazu galicyjskiego szkolnictwa. Z pamiętnika Rafata Taubenschlaga, w: Galicja i jej dziedzictwo, red. K. Szmyd, J. Dybiec, t. 20: Historia wychowania. Misja i edukacja, Rzeszów 2008, s. 193-205; „Lwów dziennikarski” we wspomnieniach Stanisława Łempickiego, w: Orientacje i kierunki w badaniach historyczno-pedagogicznych, red. I. Michalska i G. Michalski, Łódź 2009, s. 214-224.

2 Wienfried Schülze, ur. w 1942 r. w Bergisch Gladbach - historyk i metodolog niemiecki. Autor tekstu pt. Ego-Dokumente. Annäherung an den Menschen in der Geschichte (Selbstzeugnisse der Neuzei t. 2), w: Ego-Dokumente. Annäherung an den Menschen in der Geschichte, red. W. Schülze, Berlin 1996, s. 11-30.
} 
śmiennictwie polskim, zwłaszcza z zakresu historii i historii literatury, najczęściej na określenie źródeł, które są związane z historiami osobistymi i mają charakter biograficzny, używa się pojęcia literatura pamiętnikarska, przekazy pamiętnikarskie, dokumenty pamiętnikarskie lub literatura dokumentu osobistego. W ostatnich czasach, zwłaszcza w literaturze holenderskiej i niemieckiej, na oznaczenie tego rodzaju źródeł zaczęto posługiwać się terminem „ego-dokument" ${ }^{3}$. Na gruncie holenderskich badań szczególnie interesujące osiągnięcia w tym obszarze stały się udziałem R. Dekkera ${ }^{4}$ i A. Baggerman ${ }^{5}$ związanych z Uniwersytetem Erazma z Rotterdamu. Są oni autorami ważnych projektów badawczych z wykorzystaniem ego-dokumentów. Mówiąc o ego-dokumentach, nie sposób nie przywołać nazwiska jednego z najwybitniejszych na świecie znawców pisarstwa autobiograficznego i dzienników osobistych - P. Lejeune'a ${ }^{6}$. $\mathrm{Na}$ gruncie polskim, oprócz licznych publikacji historyków i metodologów poświęconych wartości dokumentu osobistego, ważne są wypowiedzi na ten temat historyków literatury. Tu warto wspomnieć o pracach M. Czermińskiej ${ }^{8}$ poświęconych autobiografii i autobiograficzności oraz I. Skwarek ${ }^{9}$. W badaniach pedagogicznych zaś na uwagę zasługują publikacje W. Dróżki, dotyczące wykorzystania materiałów autobiograficznych w badaniach pedeutologicznych ${ }^{10}$.

3 Terminu ego-dokument jako pierwszy użył Jacques Presser (1899-1970) holenderski historyk, pisarz i poeta.

${ }_{4}$ Rudolf Dekker, ur. 1951 r. w Amsterdamie - holenderski historyk. Do 2010 r. wykładowca historii w Uniwersytecie Erazma z Rotterdamu, od 1983 r. rozpoczął realizację projektu polegającego na spisie dokumentów osobistych powstałych między średniowieczem a XX w. W publikacjach pokazuje, w jaki sposób dokumenty osobiste mogą być wykorzystywane $\mathrm{w}$ badaniach historycznych.

5 Arianne Baggerman, ur. 1959 r. w Schiedam - holenderska historyk, wykładowca historii w Uniwersytecie Erazma z Rotterdamu. Autorka projektu pt. „Kontrolowanie czasu i kształtowanie ja".

6 Philippe Lejeune, ur. 1938, wykładowca literatury na Uniwersytecie Paris-Nord, współzałożyciel i działacz Stowarzyszenia na Rzecz Autobiografii i Dziedzictwa Autobiograficznego. Autor m.in. Wariacji na temat pewnego paktu. O autobiografii, red. R. Lubas-Bartoszyńska, przeł. W. Grajewski i in., Kraków 2001.

7 Warto m.in. sięgnąć do prac takich autorów jak: A. Cieński, A. Giza, W. Czapliński, F. Jakubczak, J. Maternicki, E. Podgórska, J. Trzynadlowski .

8 Jest autorką m.in. książki pt. Autobiograficzny trójkąt : świadectwo, wyznanie $i$ wyzwanie, Kraków 2000 i redaktorką wartościowego zbioru tekstów pt. Autobiografia, Gdańsk 2009, t. 9, Archiwum przekładu „Pamiętnika Literackiego”.

${ }^{9}$ I. Skwarek, Dlaczego autobiografizm? Powieści autobiograficzne dwudziestolecia międzywojennego, Katowice 1986.

10 Zob. m.in. prace tej autorki pt. Nauczyciel, autobiografia pokolenia. Studia pedeutologiczne i pamiętnikarskie, Kielce 2002; Młode pokolenie nauczycieli. Studium autobiografii młodych nauczycieli polskich lat dziewięćdziesiatych, Kielce 1997. 


\section{Gatunki ego-dokumentów i ich charakter biograficzny}

Ego-dokumenty to źródła, które zawierają autopercepcję i prezentację historycznego wydarzenia, osoby/osób, instytucji, obiektu. Są to teksty powstające jako efekt dobrowolnego lub przymusowego oświadczenia, raportu, sprawozdania, czyli dokumenty będące rezultatem przedstawienia osobistego świadectwa na temat siebie i innych osób oraz wydarzeń. Wspólną cechą wszystkich tekstów, które można określić jako ego-dokumenty jest to, że jako oświadczenia (zeznania, wyznania) dobrowolne lub wymuszone, choć stanowią wycinek określonej rzeczywistości, to dają jednak pewien obraz postrzegania nie tylko innych, ale siebie samego (czyli autora) w rodzinie, społeczności, środowisku, kraju lub klasie społecznej. Zawierają informacje odzwierciedlające stosunek autora/ów do systemów wartości i ich ewolucji na przestrzeni czasu. Ujawniają też stan wiedzy i doświadczenia życiowe. Wreszcie, ego-dokumenty uzasadniają, tłumaczą, usprawiedliwiają, przekonują o sensie zachowań indywidualnych, ludzkich.

Do klasycznych ego-dokumentów zalicza się: życiorysy, wspomnienia, dzienniki, pamiętniki, autobiografie, listy ${ }^{11}$. Każdy z tych gatunków posiada inne cechy charakterystyczne, odróżniające go od pozostałych, a i niekiedy w obrębie każdego gatunku wspomnianych źródeł można wymienić różne ich rodzaje $^{12}$. Każdemu też z wymienionych tu gatunków ego-dokumentów przyświeca inna intencja, którą przyjmują ich autorzy w pracy nad nimi i która wpływa na prezentowane treści.

Wspólną cechą materiałów źródłowych zwanych ego-dokumentami, jak już wspomniano, jest ich charakter biograficzny. Dlatego są one ważne szczególnie dla tych badaczy, dla których głównym przedmiotem badań jest biografistyka ${ }^{13}$.

11 Także wypowiedzi w zapisach urzędowych, zapisach procesów prawnych i ekonomicznych, do których zliczyć można: petycje, ankiety, testamenty, raporty przesłuchań itp. Są one niezbędne do badań w tzw. historii społecznej.

12 Przykładowo J. Trzynadlowski, mówiąc o pamiętnikach, wymienia m.in.: pamiętnik monograficzny, pamiętnik historia, pamiętnik zbeletryzowany, pamiętnik mozaikowy, pamiętnik albumowy i konfesyjny, patrz: J. Trzynadlowski, Struktura relacji pamiętnikarskiej, w: Księga pamiątkowa ku czci Stanisława Pigonia, red. Z. Czerny i in., Kraków 1961, s. 577-583. Z kolei F. Jakubczak wśród pamiętnikarskich biografii wyróżnił: biografię-kronikę, biografię-samoobronę, biografię-wyznanie, biografię-samoanalizę, patrz: F. Jakubczak, Metodologiczne problemy użytkowania dokumentów pamiętnikarskich w badaniach nad kultura współczesna, w: Ruch pamiętnikarski i przemiany polskiej kultury, red. B. Gołębiowski, J. Kossak, K. Krzemień, Warszawa 1972, s. $87-88$.

${ }_{13}$ Na temat biografistyki w historii edukacji patrz: C. Majorek, Rola badań biograficznych w rekonstrukcji dziejów oświaty i pedagogiki w Galicji, w: Biografie pedagogiczne. Szkice do portretu 
Ich biograficzny charakter wynika z faktu, że są związane z losem konkretnych jednostek. W przypadku wydań tego typu dokumentów, które są przykładem zbiorowego wysiłku przedstawicieli różnych grup społecznych, powstają niejako wspólnie tworzone historie, na które składają się świadectwa indywidualne. Wskazanie na różnice znamionujące tego rodzaju materiały jest niezwykle pomocne przy ich analizie i odpowiedzi na pytanie, jaką wartość poznawczą przedstawiają konkretne ego-dokumenty. Klasyfikacje ego-dokumentów są pomocne także w poznawaniu motywów podjęcia tego rodzaju pisarstwa przez danego autora/autorów, a to z kolei rzuca światło na wartość zawartych w nich informacji. Jak powszechnie wiadomo, pamiętnik, autobiografia, dziennik stanowią trzy podstawowe rodzaje literatury dokumentu osobistego. Chociaż trzeba zaznaczyć, że pamiętnik różni się w zasadniczy sposób od autobiografii i dziennika. Wyznacznikiem odróżniającym te gatunki dokumentu osobistego jest czas. W pamiętniku i w autobiografii wydarzenia są odtwarzane, w dzienniku pisane na bieżąco. W tym kontekście możemy mówić, że pamiętnik jest najbardziej podobny do autobiografii. W pamiętniku uwaga autora skupia się na wydarzeniach i osobach zewnętrznych towarzyszących jego życiu. W autobiografii autor koncentruje się przede wszystkim na sobie, swoich czynach, kolejnych etapach życia, przełomach w swojej biografii oraz wyznawanym systemie wartości, sukcesach i porażkach, a niekiedy skupia się po prostu na przedstawieniu własnej legendy. Autobiografia jest więc próbą samopoznania, autorzy autobiografii bowiem podejmują się spisania własnej historii, a dzięki temu powstaje dzieło literackie będące swoistego rodzaju wglądem w ich osobowość. Dla historii nauki niezwykle ważne są autobiografie naukowe, określane jako intelektualne. Często, gdy autobiografie wskazują drogę naukową autora i jego związki z określoną dyscypliną, przyjmują nazwy dyscyplin naukowych jako dookreślenie jego historii życia. $Z$ nowszych wydań dzieł autobiograficznych warto wymienić autobiografie filozofów m.in. K. Jaspersa, P. Ricoeura, H.-G. Gadamera ${ }^{14}$, autobiografie historyka K. Górskiego ${ }^{15}$ i pedagoga W. Okonia ${ }^{16}$.

galicyjskiej pedagogii, red. C. Majorek, J. Potoczny, t. 9: Galicja i jej dziedzictwo, Rzeszów 1997, s. 11-24; W. Szulakiewicz, Biografistyka i jej miejsce w historiografii edukacyjnej po II wojnie światowej, „Biuletyn Historii Wychowania” 2004, s. 5-14; Biografistyka w polskiej historiografii edukacyjnej, w: Powiazania rodzinne wśród twórców polskiej teorii i praktyki, red. W. Jamrożek, K. Kabacińska, K Ratajczak, Poznań 2007, s. 9-33.

14 H.-G. Gadamer, Moja droga do filozofii. Wspomnienia, przeł. J. Wilk, Wrocław 2000; K. Jaspers, Autobiografia filozoficzna, przeł. i przypisami opatrzył S. Tyrowicz, Toruń 1993; P. Ricour, Refleksja dokonana. Autobiografia intelektualna, przeł. P. Bobowska-Nastarzewska, Kęty 2005.

15 K. Górski, Autobiografia naukowa, red. W. Sierdzan, Toruń 2003.

16 W. Okoń, Samo życie osiemdziesięciolatka z autobiografia naukowa autora, Warszawa 2005. 
Jeszcze innym, chyba niedocenianym, źródłem - zwłaszcza w obszarze nauk o wychowaniu - jest korespondencja. Dlatego w tym miejscu warto przywołać opublikowane przez W. Theissa Listy o pedagogice społecznej ${ }^{17}$, które słusznie są traktowane przez redaktora jako źródło wiedzy o dziejach pedagogiki społecznej. Listy o pedagogice społecznej dokumentują historię kształtowania się teoretycznych podstaw tej dyscypliny, jej instytucjonalizacji i osób biorących udział w tym dziele tworzenia. Wartość tego zbioru ego-dokumentów polega na tym, że obejmuje on długi okres historyczny, bo lata 1906-1975. Drugim ważnym zbiorem listów jest publikacja zawierająca korespondencję M. Grzegorzewskiej ${ }^{18}$. I chociaż jest wiele opracowań poświęconych twórczyni pedagogiki specjalnej, to ten zbiór listów odsłania wiele nowych aspektów jej działalności w kontekście aktywności na rzecz kształtowania się pedagogiki specjalnej i relacji z ludźmi z jej otoczenia. Listy M. Grzegorzewskiej pokazują także, jak ważnym ,narzędziem” pracy dla niej była korespondencja.

W dzisiejszych czasach możemy mówić nie tylko o wartości tradycyjnej korespondencji (papierowej), ale wymianie informacji drogą elektroniczną. Te dwie formy korespondencji różnią się jednak. Zestawiając te dwa rodzaje korespondencji, można stwierdzić, że o ile wymiana informacji drogą elektroniczną, którą można określić jako tzw. korespondencję urzędową, jest w pewnym sensie podobna do korespondencji tradycyjnej, o tyle korespondencja między uczonymi w wersji papierowej i elektronicznej różni się zasadniczo, zarówno jeśli chodzi o treść, która jest niezwykle „uboga”, jak i kulturę języka. Najczęściej korespondencja mailowa ogranicza się do podania suchych informacji dotyczących określonego problemu, często przypomina tradycyjny telegram.

\section{Ograniczenia ego-dokumentów}

Trzeba stwierdzić, że chociaż ego-dokumenty są uznawanym źródłem wiedzy, to ciągle wielu badaczy odnosi się do tego rodzaju materiałów źródłowych sceptycznie. Wątpliwości wyrażane przez zainteresowanych tymi źródłami dotyczą wartości (prawdziwości) zawartych w nich informacji. Źródłom tym bowiem zarzuca się głównie racjonalizację faktów, a tym samym subiektywizm w przedstawianiu obrazu/obrazów przeszłości. W literaturze na temat interesujących nas źródeł podejmowano próby poszukiwania przyczyn powodujących

17 Listy o pedagogice spolecznej, Helena Radlińska, Aleksander Kamiński, Adam O. Uziembło, red. W. Theiss, Warszawa 1997.

${ }_{18}$ Marii Grzegorzewskiej listy do przyjaciót, wybór i oprac. E. Tomasik, Warszawa 2002. 
deformację prawdy historycznej zawartej w ego-dokumentach. Wśród polskich autorów - jako przykład można wskazać B. Gołębiowskiego i A. Cieńskiego - wyznawany jest pogląd, iż sprawa prawdy w źródłach wiąże się m.in. z motywami spisywania pamiętników ${ }^{19}$. Podobnego zdania na ten temat był francuski filozof G. Gusdorf, który przedstawiając rozważania na temat ograniczeń autobiografii, uznał, że wynikają one głównie z intencji autora doku$m^{m e n t u}{ }^{20}$. Przy czym poszczególnym gatunkom ego-dokumentu przyświeca inny motyw/y, co więcej motywy te mogą się zmieniać w trakcie powstawania dokumentu. Dzieje się tak np. wtedy, gdy ego-dokument powstaje przez wiele lat. Z taką sytuacją spotykamy się w przypadku dzienników M. Dąbrowskiej, która stwierdziła: „Zaczęłam pisać dziennik z początkiem pierwszej wojny światowej w przekonaniu, że żyję w wielkiej epoce, w której każdy co najmniej ociera się o fakty warte zanotowania. Tymczasem z biegiem lat historia znikła z kart mojego dziennika i nie notowane są nawet fakty dziejowe, które odegrały bezpośrednią rolę w moim życiu, jeśli nie zewnętrznym to duchowym"21. Wśród innych czynników powodujących „deformację” prawdy, wymienia się zjawisko określane jako tzw. nie-dopisanie i nad-pisanie ${ }^{22}$. Badacz jednak musi pamiętać, że pominięcie pewnych faktów (nie-dopisanie), czyli milczenie źródła na określony temat lub przedstawienie informacji, których zaistnienia nie potwierdzają inne źródła (nad-pisanie), są także elementami autoprezentacji autora i przejawem istotnych informacji o autorze dokumentu. Badacz musi w tej sytuacji postawić pytanie: „dlaczego coś zostało przemilczane?” lub odwrotnie, „dlaczego coś zostało dopisane, chociaż w świetle innych źródeł okazuje się, że nie miało miejsca?". Na inne przyczyny deformacji prawdy zwrócił uwagę W. Czapliński, wymieniając trzy podstawowe powody: zawodność pamięci, naturalną tendencję do przedstawienia własnej osoby w dobrym świetle oraz częste uleganie własnym sympatiom $\mathrm{i}$ antypatiom w stosunku do innych osób ${ }^{23}$. Pierwszy z wymienionych argumentów (zawodność pamięci) ma istotne zna-

19 Więcej na ten temat: A. Cieński, Z dziejów pamiętników w Polsce, Opole 2002, s. 41-46; B. Gołębiowski, Pamiętnikarstwo i literatura. Szkice z socjologii kultury, Warszawa 1973, s. 93 i n.

20 G. Gusdorf, Warunki i ograniczenia autobiografii, w: Autobiografia, red. M. Czermińska, Gdańsk 2009, s. 32 i n.

21 M. Dąbrowska, Dzienniki 1914-1945. Wybór, wstęp i przypisy T. Drewnowski, Warszawa 1998, s. 285. W tomie tym zostały opublikowane interesujące refleksje Dąbrowskiej na temat sensu pisania dzienników, tamże, s. 285-286.

22 Cyt. za: A. Cieński, dz. cyt., s. 36-37.

23 W. Czapliński, Pamiętnik jako źródło dla historyka nowożytnego, „Pamiętnikarstwo Polskie” 1972, nr 2, s. 2-7. 
czenie dla prawdziwości zapisanych faktów w pamiętnikach, wspomnieniach, autobiografii. Dlatego wielu autorów ego-dokumentów już na samym początku swych dzieł zastrzega, iż mogą się mylić w dokładnym określeniu czasu czy okoliczności, w jakich dany fakt miał miejsce ${ }^{24}$. Ważna więc w kontekście rozpoznawanych ograniczeń ego-dokumentów jest pamięć, zarówno indywidualna, jak i zbiorowa, oraz problem odróżnienia pamięci jako intencji i wspomnienia jako rzeczy będącej przedmiotem tej intencji ${ }^{25}$. O roli i właściwościach pamięci w tworzeniu wspomnień pisał w swej autobiografii naukowej W. Tatarkiewicz, wskazując, że ze wspomnieniami wiążą się tzw. zjawiska pamięci. Do nich zaliczył: zjawisko sprasowania wspomnień w pamięci, zjawisko przypadkowości pamięci, czyli to, dlaczego w pamięci został ten obraz, a nie inny, zjawisko zbitki, czyli powstania jednego obrazu z wielu, zjawisko atrakcyjności, zjawisko pośredniości, zjawisko przewagi wspomnień dziecięcych i zjawisko przewagi wspomnień niecodziennych ${ }^{26}$. Jako przykład sprasowania i przypadkowości pamięci w kontekście wspomnień W. Tatarkiewicz wskazał na wspomnienia szkolne. Wątpliwości, co do sensu pisania wspomnień, ze względu na zawodność pamięci, wyraziła B. Skarga, stwierdzając: „Piszący czuje, że patrzy wstecz z zupełnie innej perspektywy i nie jest wstanie oddać autentycznego obrazu swych przeżyć! A ileż postaci, głosów, zdarzeń jawi się jak ledwie widoczny ślad... Czy można się przedrzeć przez mgłę własnego zapomnienia?"27. I chociaż na subiektywny charakter literatury pamiętnikarskiej zwróciło uwagę wielu autorów, to sytuacja w kwestii uznawania wartości tego źródła zmieniła się, można powiedzieć, na jego korzyść w związku z przekonaniem o słuszności tworzenia tych dokumentów oraz konieczności ich wykorzystywania w badaniach naukowych. Jak ważne jest spisywanie wspomnień, mówił S. Lam, historyk literatury, krytyk literacki, wydawca. Łącząc fakt pisania wspomnień z wiekiem podeszłym, podkreślał, że pisać wspomnienia powinni zwłaszcza ci, którzy odgrywali ważną rolę w życiu społecznym. Bo jego zdaniem: ,jeśli

\footnotetext{
24 Przykładem niech będzie stwierdzenie wyrażone przez M. Falskiego: „Nie mam jednak pamięci rozleglej i ograniczam się do faktów stosunkowo nielicznych, które jak mi się wydaje, pamiętam dość dokładnie. Mogę się nieraz mylić w szczegółach, zwłaszcza w określeniu czasu i okoliczności w jakich ten lub ów fakt miał miejsce", M. Falski, w: Z okruchów wspomnień, oprac. i przypisy. M. Kossecka, wstęp A. Ossowska-Zwierzchwoska, Bydgoszcz 2007, s. 5.

25 Interesujące poglądy na temat pamięci i historii głosił P. Ricoeur w publikacji pt. Pamięć, historia, zapomnienie, przeł. J. Margański, Kraków 2006, s. 123-185 i J. Le Goff, rozpatrując zagadnienie rozwoju pamięci w poszczególnych okresach historycznych i jej przemian (Historia i pamięć, przeł. A. Gronowska, J. Stryjczyk, wstęp P. Rodak, Warszawa 2007, s. 101-157).

26 T. Tatarkiewicz, W. Tatarkiewicz, Wspomnienia, Poznań 2011, s. 183-184.

27 B. Skarga, Po wyzwoleniu... 1944-1956, Poznań 1990, s. 5.
} 
starzec spędził swoje życie na wielkiej arenie świata, jeśli był mężem stanu, politykiem, czy pisarzem i z wspomnień swoich zwierza się w książce - nic milszego jak odczytywać te karty i z nich dowiadywać się o zakulisowych tajnikach spraw dużych dla historii, a czasem małych w poczęciu, o ludziach sławnych dla potomności, a szarych dla współczesnych, o wypadkach co wstrząsały kiedyś, a z odległości wydają się nikłe"28. Świetnym przykładem ilustrującym słuszność twierdzenia mówiącego, że wspomnienia powinni pisać ci, którzy odegrali ważną rolę w życiu społecznym, są literackie wspomnienia o J. Piłsudskim autorstwa K. Iłłakiewiczówny, z okresu pracy poetki w Ministerstwie Spraw Wojskowych ${ }^{29}$. Z kolei dopełnieniem obrazu tej wybitnej poetki, występującej też w roli pedagoga, są wspomnienia J. Ratajczaka, poety i prozaika, opowiadające o edukacji u K. Iłłakiewiczówny ${ }^{30}$. Idąc więc tropem S. Lama, wskazującego, jakie osoby szczególnie powinny tworzyć ego-dokumenty, do jego listy ludzi ważnych w życiu społecznym należy dołączyć też wybitnych pedagogów, których idee i doświadczenia pedagogiczne są ważnym elementem w procesie zrozumienia współczesnej rzeczywistości edukacyjnej. W tym kontekście dodać warto, iż jako argument w obronie wartości przekazów pamiętnikarskich wymienia się w literaturze to, że odgrywają one ważną rolę w procesie przekazywania tradycji ${ }^{31}$. Słusznie więc $\mathrm{S}$. Łempicki, chociaż był świadom ograniczeń spisywanych przez siebie wspomnień (mowa tu o Wspomnieniach Ossolińskich), napisał: „We wspomnieniach może i pięknieje niejedno: może zaciera się czasem to, co było cieniem lub plamą. Prawda w zasadniczych konturach jawi się jednak niezmieniona; zachowała się żywa i młoda w cieple ludzkiego serca" ${ }^{32}$. Na tej podstawie można powiedzieć, że ego-dokumentom zapewne zawdzięczamy, używając słów S. Łempickiego, „kontury prawdy” i na tym polega przede wszystkim ich wartość.

\section{Pytania stawianie ego-dokumentom a ich wartość poznawcza}

Każdy badacz, aby ocenić wartość poznawczą wykorzystywanego ego-dokumentu dla prowadzonych badań, musi postawić szereg pytań i znaleźć na nie

\footnotetext{
28 S. Lam, Życie wśród wielu, przygot. do druku A. Lam, Warszawa 1968, s. 5.

29 K. Iłłakiewiczówna, Ścieżka obok drogi, wyd. 2, Warszawa 1939.

30 J. Ratajczak, Lekcje u Iłłakiewiczówny (szkice, wspomnienia, listy i wiersze), Poznań 1986.

31 Taką tezę głosił m.in. J. Kozakiewicz, występując w obronie znaczenia przekazów pamiętnikarskich w badaniach naukowych, patrz: J. Kozakiewicz, Pamiętniki jako źródta oraz ich funkcja w procesie kształtowania świadomości społecznej, „Historyka” 1982, t. 12, s. 131.

${ }^{32}$ S. Łempicki, Wspomnienia ossolińskie, Wrocław 2006, s. 6.
} 
odpowiedzi. Do podstawowych pytań stawianych źródłom, jak powszechnie wiadomo, należą m.in. pytania o: 1. czas powstania dokumentu, 2. okoliczności powstania, 3. autora dokumentu (kim jest/ był?), 4. motywy spisania dokumentu. Lista wymienionych pytań, które należy postawić tym źródłom, nie jest tu wyczerpana, jest ona o wiele dłuższa ${ }^{33}$. Wymienione pytania są istotnymi wskazówkami w pracy badacza. Nie wchodząc jednak w metodologiczne szczegóły poszukiwania informacji przy pomocy wszystkich sformułowanych tu pytań, warto zatrzymać się przynajmniej na dwóch ostatnich (chodzi o autora i motyw), które są niezwykle ważne w procesie badania. Pozwalają one uzyskać głębszą wiedzę o autorze dokumentu ego i motywach jego spisania, a te informacje w zasadniczy sposób są pomocne w pozyskaniu wiedzy źródłowej.

Wiedza o autorze jest bezcenna w odczytaniu wartości konkretnego dokumentu. Jednak w przywoływanych poniżej przykładach ograniczę się jedynie do podania nazwisk autorów lub bardzo skrótowych informacji, gdyż są oni powszechnie znani polskiemu czytelnikowi. Skoncentruję się natomiast na motywach spisywania dokumentów. Mają one niebagatelne znaczenie w odczytaniu wartości poznawczej ego-dokumentów. A. Cieński, pisząc o motywach spisywania pamiętników, wyróżnia dwa ich rodzaje: zewnętrzne i wewnętrzne. „Zewnętrznymi nazywamy tu takie - pisze - które mają przynieść autorom jakąś korzyść, które są obliczone na zmianę stosunku innych do autora. Wewnętrzne zaś to takie, które mają na celu zaspokojenie jakichś głębszych potrzeb psychicznych [...], a więc powinny spowodować zmianę stosunku autora do samego siebie” 34 . Dalej ten sam autor stwierdza: „Na pierwszym miejscu w tej hierarchii należy umieścić motyw związany z oceną własnego życia. Może to być ocena własnej drogi życiowej, swoiste obejrzenie się wstecz, prowadzące do odpowiedzi na pytanie, co osiągnąłem, co mi się udało, kiedy postępowałem dobrze, a kiedy źle" ${ }^{35}$. Ważnych informacji o motywach pisania dzienników dostarcza nam w swych pracach wspomniany już P. Lejeune. Pisząc o praktyce powstawania dzienników, wymienia on kilka motywów ich pisania. W jego opinii autorzy dzienników piszą, ponieważ chcą m.in.: zachować w pamięci swoje życie i stworzyć pewną narracyjną tożsamość; przetrwać; zwierzyć się; poznać siebie, rozważać i zbilansować swoje dotychczasowe życie; wytrzymać w trudnych momentach życia, gdy zostajemy poddawani próbie; myśleć, bowiem zapisywanie dziennika traktuje się jako metodę pracy i wreszcie ulubione zajęcie,

33 Dla określenia wartości ego-dokumentów ważne są inne kryteria, takie jak: wiek, płeć, rasa, wykształcenie, doświadczenie, pozycja społeczna i wyznawane wartości.

${ }_{34}$ A. Cieński, dz. cyt., s. 45.

35 Tamże, s. 46. 
czyli piszemy dziennik, bo lubimy pisać ${ }^{36}$. W wielu opracowaniach pojawia się też teza o terapeutycznym znaczeniu tworzenia ego-dokumentów i ten motyw stawia się jako podstawowy w ich powstawaniu. Tworzenie historii życia ma więc w takim kontekście podłoże psychologiczne ${ }^{37}$.

Ogólnie można stwierdzić, że wspomnienia, pamiętniki i autobiografie to opowieści ich autorów o samym sobie, to jakby wędrówka z samym sobą przez życie. Dlatego autorzy tego gatunku literackiego wskazują aspekt przebytej drogi życiowej już nawet $w$ tytule swych prac ${ }^{38}$. Tym samym przyświeca im określony cel, jest nim zaproszenie czytelnika do wspólnego przebycia tej drogi, czy też wielu dróg, gdy historie życia obfitują w bogactwo wydarzeń. I chociaż ten gatunek pisarski nie ma do końca ustalonych reguł, spełnia jednak pewien warunek. Tym podstawowym warunkiem jest celowość ujawnienia czytelnikowi osobistego doświadczenia życiowego, podzielenia się nim z innymi, zaprezentowania tego, co przeżyli lub co stworzyli. Zdarza się, że autorzy wspomnień zwracają się bezpośrednio do potencjalnych adresatów, ujawniając swe intencje. Niekiedy też swój projekt dostosowują do odpowiednich adresatów oraz ewentualnego horyzontu ich oczekiwań czy wzorców, reguł i strategii rozumowania. Przytoczmy kilka przykładów, potwierdzających słuszność tej tezy, oddając głos autorom, którzy sami jasno i jednoznacznie określają istotę swych dokumentów osobistych, ujawniając główny motyw ich tworzenia.

Ze znanej nam literatury historyczno-pedagogicznej przykładem w tej kwestii są Wyznania J. J. Rousseau, w których zwraca się do czytelnika tymi słowy: „Chcę pokazać moim bliźnim człowieka w całej prawdzie jego natury; a tym człowiekiem będę ja" ${ }^{39}$. Z kolei M. Tyrowicz, wybitny historyk. w publikacji pt. W poszukiwaniu siebie. Pod lwowskim niebem, określając istotę swego przedsięwzięcia pisarskiego, mówił: „Pragnę bowiem opowieść o swym życiu i pochodzeniu rodzinnym zamknąć w rozdziałach, stanowiących jakby odrębne tematyczne części. Tak więc w obrazach odleglejszej i bliższej przeszłości zawieść może nić Ariadny, powtórzą się pewne fakty i szczegóły, urwać się może ciągłość biograficzna, grozi to tym bardziej, że działałem w mym ży-

${ }^{36}$ P. Lejeune, ,Drogi zeszycie...”, ,,drogi ekranie...”. O dziennikach osobistych, przeł. A. Karpowicz, M. Rodak, P. Rodak, wybór, wstęp i oprac. P. Rodak, Warszawa 2010, s. 39-42.

${ }_{37}$ Mam na myśli publikacje: W. Mckinley Runyan, Historie życia a psychobiografia. Badania teorii i metody, przeł. J. Kasprzewski, Warszawa 1992; D. Demetrio, Autobiografia. Terapeutyczny wymiar pisania o sobie, przeł. A. Skolimowska, przedmowa O. Czerniawska, Kraków 2000.

38 Jako przykłady wymieńmy: Z. Mysłakowski, Zatracone ścieżki, zagubione ślady, Warszawa 1967; N. Żmichrowska, J. Baranowska, Ścieżki przez życie. Wspomnienia, oprac. M. Romankówna, wstęp Z. Kossak, Wrocław 2006.

39 J. J. Rousseau, Wyznania, przeł. i wstępem opatrzył T. Żeleński (Boy), Warszawa 1956, s. 65. 
ciu w różnych dziedzinach, wśród różnych ludzi, na różnych terenach”. I dalej: „Panie i Panowie! - pozwólcie, że się wam przedstawię...!”40. A wyjaśniając jednoznacznie motyw pisania wspomnień, dodał: „Poszukiwałem prawdy nie tylko o egzystencjach czasów minionych, ale - i być może przede wszystkim poszukiwałem siebie samego" $"$.

Innym przykładem w interesującej nas kwestii jest publikacja T. Tomaszewskiego, wybitnego polskiego psychologa. Pozostawił po sobie niezwykły dokument, który został zatytułowany Lwów 1940-1944. Pejzaż psychologiczny, będący zbiorem notatek prowadzonych w trudnym okresie jego życia i życia wielu Polaków. T. Tomaszewski, określając istotę aktywności dokumentowania wydarzeń i osób, dzięki której wiele lat po wojnie powstała publikacja, napisał: „Prowadziłem te notatki jako psycholog, z myślą o przyszłych uogólnieniach, może o napisaniu pracy naukowej o tym, jak postrzegają sytuację polityczną ludzie, którzy sami są w niej uwikłani”"42. Jeszcze inaczej cel zaprezentowania swych wspomnień sformułował J. Iwaszkiewicz, który we Wstępie Książki wspomnień, napisał: „Nie, nie mam zamiaru pisać, wyznań ani spowiedzi... Mnie tylko będzie chodziło o to, aby opowiedzieć jak świat zewnętrzny z całym jego pięknem, z całą szpetotą, tragizmem i radością przełamywał się w duszy dziecka, młodzieńca i mężczyzny, i jak przygotowywałem się do spełnienia trzech zadań, które sobie postawiłem w zaraniu życia, aby możliwie najdokładniej ten świat poznać, zrozumieć i wyrazić" ${ }^{43}$.

Niezwykle wyraziście cel ogłoszenia drukiem swoich wspomnień przedstawiła K. Lanckorońska, wybitna historyk sztuki, działaczka polonijna w Rzymie. W przedmowie do wspomnień z okresu drugiej wojny jednoznacznie określiła intencję, która jej przyświecała w przekazaniu czytelnikom świadectwa tamtych lat, pisząc: „Pamiętnik ten ma być sprawdzianem z tego, czego byłam świadkiem w czasie II wojny światowej" ${ }^{44}$. Podobnie intencję swych wspomnień określił K. Żygulski, socjolog kultury, który pisząc o ludziach, wydarzeniach i przeżyciach związanych ze Lwowem, stwierdził: „Wspomnienia moje dotyczą czasu przeszłego dokonanego [...] Moje wspomnienia [...] są relacją osobistą i tylko osobistą, opisują to w czym brałem udział. Tak się jed-

40 M. Tyrowicz, W poszukiwaniu siebie. Wspomnienia i refleksje, t. 1: Pod lwowskim niebem, Lublin 1988 s. 7.

41 Tamże, s. 25.

42 T. Tomaszewski, Pejzaż psychologiczny, Warszawa 1996, s. 8.

43 J. Iwaszkiewicz, Ksiażka moich wspomnień, Poznań 2010, s. 7.

44 K. Lanckorońska, Wspomnienia wojenne. 22 IX1939-5 IV 1945, słowo wstępne L. Kalinowski, E. Orman, Kraków 2003, s. 15; tejże, Szkice wspomnień, przedmowa A. Biernacki, Warszawa 2005. 
nak złożyło, że w latach trzydziestych i czterdziestych uczestniczyłem w wielu wydarzeniach, działaniach, czy instytucjach, które mogą także w jakimś stopniu zainteresować historyka, zwłaszcza tego, którego ciekawią dzieje oświaty, organizacji młodzieżowych, ruchów politycznych i wreszcie państwa podziemnego okresu okupacji ${ }^{45}$.

\section{Znaczenie ego-dokumentów w badaniach historii pedagogiki, oświaty i nauki}

W dotychczasowej literaturze spotyka się różnorodne definiowanie znaczenia dokumentu osobistego jako źródła w badaniach naukowych. Przy czym mówi się o ich wartości poznawczej w badaniach naukowych, a także o wartości edukacyjnej i wykorzystaniu w obszarze dydaktyki. Na wartość literatury pamiętnikarskiej w dydaktyce zwrócił uwagę m.in. J. Maternicki ${ }^{46}$. W badaniach historycznych dokumenty osobiste traktuje się często jako źródło kultury historycznej $^{47}$, ale i świadectwo świadomości historycznej oraz historii mentalności jednostek i grup społecznych. J. Chałasiński uznawał pamiętnikarstwo polskie za świadectwo przeobrażeń narodu polskiego $0^{48}$. Ale tego rodzaju materiały mogą być niezbędnym źródłem w badaniach historii pedagogiki i oświaty, historii myśli pedagogicznej, biografistyki pedagogicznej, historii nauki, w tym dziejów powstawania szkół naukowych, a także pedeutologii historycznej ${ }^{49}$.

45 K. Żygulski, Jestem z lwowskiego etapu..., Warszawa 1994, s. 8.

46 J. Maternicki, Materiały autobiograficzne i ich funkcja poznawcza i dydaktyczna, w: tegoż, Historia i wychowanie, Warszawa 1990, s. 220.

47 Więcej na ten temat: tenże, Pamiętnik jako dokument kultury historycznej, „Przegląd Humanistyczny" 1985, nr 11-12, s. 231-262.

48 J. Chałasiński, Pamiętnikarstwo jako świadectwo przeobrażeń narodu polskiego, w: Pamiętniki Polaków 1918-1978. Antologia pamiętnikarstwa polskiego, t. 1: Druga Rzeczpospolita 1918-1939, wstęp J. Chałasiński, J. Szczepański, wybór i oprac. B. Gołębiowski, M. Grad, F. Jakubczak, Warszawa 1982, s. 9-29.

49 Wartość dokumentów osobistych pokazuję m.in. w następujących opracowaniach: Dziedzictwo naukowe Uniwersytetu Jagiellońskiego i Uniwersytetu Lwowskiego okresu autonomii galicyjskiej. Mistrzowie i seminaria naukowe, Artes Liberales, „Zeszyty Naukowe Akademii Humanistycznej im A. Gieysztora" 2007, nr 2, s. 87-98; Pamiętnikarski portret nauczycieli w ujęciu Rafała Taubenschlaga (1881-1958), w: Z dziejów polskiej oświaty. Księga Jubileuszowa dedykowana Profesor Danucie Koźmian, red. I. Kość i E. Magiera, Szczecin 2007, s. 85-95; Rola literatury pamiętnikarskiej w rekonstrukcji obrazu galicyjskiego szkolnictwa. Z pamiętnika Rafała Taubenschlaga, w: Galicja i jej dziedzictwo, red. K. Szmyd, J. Dybiec, t. 20: Historia wychowania. Misja i edukacja, Rzeszów 2008, s. 193-205; O uczacych i uczonych. Szkic z pedeutologii historycznej, w: Wdzięczność i zobowiazanie. Myśl Jana Pawła II źródtem inspiracji współczesnego środowiska akademickiego, red. Cz. Kustra, Torun 2009, s. 43-51 oraz Opowiadając o sobie. Obraz dzieciństwa we wspomnieniach wybitnych ludzi (w druku). 
Są i mogą być wykorzystane w odtwarzaniu dziejów instytucji oświatowych, naukowych i instytucji kultury. Wreszcie są przykładem i przejawem kultury pedagogicznej i jej przemian na przestrzeni wieków.

Podajmy kilka przykładów wykorzystania dokumentów osobistych, ważnych w opracowywaniu konkretnych tematów i problemów związanych z subdyscyplinami pedagogicznymi. Otóż zapewne nie można omówić historii oświaty okresu zaborów, nie odwołując się do dokumentów osobistych, w których relacje o nauczycielach, szkole, organizacji oświaty jawią się jako ważne świadectwa składające się na wizję polityki oświatowej zaborcy ${ }^{50}$. Nie można też zrozumieć intencji reformy szkolnej z okresu międzywojennego, nie czytając wspomnień W. Jędrzejewicza ${ }^{51}$. Z kolei przedstawiając twórców koncepcji edukacyjnych, należy zapoznać się z ich osobistymi historiami opowiedzianymi przez nich samych, zawartymi w pamiętnikach i wspomnieniach. Dzięki temu łatwiej można pojąć założenia proponowanych przez nich rozwiązań edukacyjnych. Jako przykład podajmy świadectwa osobiste J. Zamoyskiej ${ }^{52}$, działaczki społecznej i założycielki „Szkoły Domowej Pracy Kobiet”, oraz błogosławionego E. Bojanowskiego ${ }^{53}$, założyciela ochronek wiejskich czy księdza i pedagoga zarazem, autora podręczników, dydaktyka religii, ks. W. Gadowskiego $^{54}$. Pięknym przykładem świadectw pedagogicznych jest zbiór wspomnień o J. Korczaku, dzięki któremu o wiele łatwiej zrozumieć nam Starego Doktora, zwłaszcza gdy połączymy je z lekturą jego zapisków pamiętnikarskich ${ }^{55}$.

Szczególny wymiar posiadają ego-dokumenty w rekonstrukcji dziejów nauki, szkół naukowych i biografii przedstawicieli różnych dyscyplin nauki, nie tylko pedagogiki, gdyż w nich zazwyczaj znajdujemy treści z zakresu pedeutologii. Oto kilka przykładów wspomnień i dzienników napisanych przez historyków (L. Kolankowskiego i S. Kalembkę), historyka literatury (K. Górskiego), historyka sztuki (K. Lanckorońską), filozofów (K. Twardowskiego i W. Tatar-

${ }^{50}$ K. Chłędowski, Pamiętniki, Galicja 1843-1880, t. 1, wstęp i przypisy A. Knot, Kraków 2006; Galicyjskie wspomnienia szkolne, do druku przygot. A. Knot, Kraków 1955; W. Gomulicki, Wspomnienia niebieskiego mundurka, Pułtusk 2007.

${ }^{51}$ W. Jędrzejewicz, Wspomnienia, oprac. i posł. J. Cisek, Wrocław 1993.

52 J. Zamoyska, Wspomnienia, Londyn 1961.

53 E. Bojanowski, Dziennik 1853-1871, wybór, wstęp i przypisy A. i T. Szafrańscy, Warszawa 1988; tenże, Korespondencja Edmunda Bojanowskiego z lat 1829-1871, t. 1: Listy Edmunda Bojanowskiego z lat 1836-1871, objaśnił, skomentował i zarysem monograficznym poprzedził L. Smołka, Wrocław 2001.

54 W. Gadowski, Wspomnienia katechety, red. A. Solak, Kraków 2002.

55 Wspomnienia o Januszu Korczaku, wybór i oprac. L. Barszczewska, B. Milewicz, Warszawa 1989 oraz J. Korczak, Pamiętnik i inne pisma z getta, przypisy M. Ciesielska, posł. J. Leociak, Warszawa 2012. 
kiewicza) i pedagogów (M. Falskiego, Z. Mysłakowskiego $)^{56}$. Nazwisk wymienionych tu autorów nie trzeba przedstawiać, gdyż są powszechnie znani, odegrali oni bowiem znaczącą rolę $\mathrm{w}$ dziejach polskiej humanistyki, nie tylko jako pisarze, ale i organizatorzy nauki polskiej oraz wybitni nauczyciele akademiccy. Przy czym trzeba także zaznaczyć, że znakomitą wartość dla historii nauki przedstawiają autobiografie naukowe, często bowiem są to „dobre” przewodniki uczonych po ich życiu. A czy bez takich przewodników można tworzyć historię nauki? Przykładem w tym obszarze tematycznym niech będą: zbiorowe dzieło pt. Uczeni polscy o sobie czy publikacje przedstawiające indywidualne autobiografie naukowe m.in. K. Górskiego i W. Okonia.

Z dziejami nauki wiążą się nierozerwalnie historie szkół wyższych, których przeszłość trudno odtworzyć, nie odwołując się do świadectw osobistych. Ilustracją ego-dokumentów dla tego tematu niech będą opublikowane wspomnienia, dokumentujące historię Katolickiego Uniwersytetu Lubelskiego i Uniwersytetu Mikołaja Kopernika. Będzie w nich głównie mowa o wybitnych uczonych pracujących w tych uczelniach ${ }^{57}$.

Niemal we wszystkich dokumentach osobistych odnajdziemy wątki dotyczące problemów wchodzących w zakres pedeutologii historycznej. Jednak niedocenianym przez badaczy źródłem wydaje się korespondencja. Dlatego jako przykład warto przywołać korespondencję pomiędzy wybitnymi polskimi humanistami, w perspektywie dialogu prowadzonego między mistrzem i uczniem. Niech egzemplifikacją będzie dialog pomiędzy I. Chrzanowski i jego uczniem S. Pigoniem, S. Kotem i M. Wajsblumem, H. Elzenbergiem i Z. Herbertem oraz H. Radlińską a jej uczniami i współpracownikami ${ }^{58}$. Z kolei dla odtwo-

56 M. Falski, dz. cyt.; S. Grzybowski, Wspomnienia, Zakamycze 1999; K. Górski, Pamiętniki, Toruń 1995; S. Kalembka, Urywki wspomnień, Toruń 2009; L. Kolankowski, Ludwik Kolankowski 1882-1956. Zapiski pamiętnikarskie, do druku przygot., wstępem i przypisami opatrzyła S. Grochowina, Toruń 2012; K. Lanckorońska, Szkice wspomnień; Z. Mysłakowski, dz. cyt.; K. Twardowski, Dzienniki, t. 1-2, Warszawa-Toruń 1997; T. Tatarkiewicz, W. Tatarkiewicz, dz. cyt.

${ }^{57}$ Katolicki Uniwersytet Lubelski w latach 1944-1952. Wspomnienia i relacje, red. J. Ziółek, Lublin 1999; Leon Jeśmianowicz (1914-1989) we wspomnieniach wspótpracowników i przyjaciót, Toruń 2009; J. Serczyk, Minęło życie, Toruń 1999, Uniwersytet Mikołaja Kopernika. Wspomnienia pracowników, Torun 1995; Uniwersytet Mikołaja Kopernika. Wspomnienia absolwentów, Torun 2009.

58 I. Chrzanowski, S. Pigoń, Mistrz i uczeń: korespondencja wzajemna (1914-1936), do druku przygot., wstępem i przypisami opatrzył Cz. Kłak, Rzeszów 2005; H. Radlińska, A. Kamiński, A. O. Uziembło, Listy o pedagogice społecznej, red. W. Theiss, Warszawa 1997; „,Zawsze bytem Żydem dla Polaków i Polakiem dla Żydów”. Listy Marka Wajsbluma do Stanistawa Kota z lat 1927-1961, oprac. i wstępem opatrzyli Z. Pietrzyk i Z. Koziński, Kraków 1996; Z. Herbert, H. Elzenberg, Korespondencja, Warszawa 2002. 
rzenia dziejów historii filozofii niemieckiej znakomitym źródłem jest, trwająca pół wieku, korespondencja H. Arendt i M. Heideggera ${ }^{59}$.

\section{Uwagi końcowe}

Podsumowując rozważania na temat wartości ego-dokumentów, należy stwierdzić, że dzięki tym źródłom uzyskujemy informacje niezbędne dla stworzenia obrazu przeszłości, takie jak klimat duchowy okresu historycznego, który nie jest możliwy do odtworzenia na podstawie innych dokumentów. Ego-dokumenty są zatem tym źródłem wiedzy, których wykorzystanie w badaniach pozwala odsłonić inne, mniej oficjalne „strony” życia jednostki, grupy społecznej, środowiska. To źródła, które są pomocne w zrekonstruowaniu genezy powstawania i funkcjonowania instytucji, o których milczą niekiedy oficjalne źródła.

Wartość dokumentów osobistych jako źródła poznania jest bezsprzeczna, ale ich wykorzystywanie w badaniach naukowych nakłada na każdego autora szczególne obowiązki. Analiza ego-dokumentów wymaga bowiem od badaczy niezwykłej rozwagi w ogólnym odczytaniu tych źródeł, ustaleniu faktów źródłowych o ludziach, wydarzeniach i instytucjach. Obliguje jednak interpretatorów do sceptycznego spojrzenia na ustalone fakty źródłowe ze świadomością, że mogą one, ale nie zawsze muszą być faktami historycznymi. Albowiem udowodnienie tego, czy fakt źródłowy jest faktem historycznym, wiąże się z koniecznością przyjmowania postawy krytycznej wobec podawanych przez autorów ego-dokumentów informacji. Przede wszystkim autorzy prac, wykorzystując w swych badaniach ego-dokumenty, muszą wykazać niezwykłą ostrożność w wysuwaniu wniosków, budowaniu uogólnień, by nie popełniali błędów polegających na uproszczeniach, bezpodstawnych uogólnieniach i budowaniu na tej podstawie fałszywych teorii o przeszłości. A jest to możliwe tylko wtedy, gdy badacz posiada rzetelną wiedzę pozaźródłową, która uchroni go przed tego rodzaju błędami. Warto jednak w badaniach naukowych pokonywać te trudności i ograniczenia, zwłaszcza w przypadku prac z historii edukacji, bo jak mawiał Profesor C. Majorek, historyk wychowania - kierując swoje badania w stronę współczesności ,postrzega [...] swoją rolę, nie tylko jako strażnika zawsze hipotetycznej prawdy, ile jako propagatora pewnych idei i rozwiązań użytecznych"60. W dziejach edukacji było wiele pięknych i mądrych idei, które

59 H. Arendt, M. Heidegger, Korespondencja z lat 1925-1975, na podstawie spuścizny obojga autorów oprac. U. Ludz, przeł. S. Lisiceka, Warszawa 2010.

60 C. Majorek, Glosa do rozważań o historii wychowania, w: Źródla do dziejów wychowania i myśli pedagogicznej, t. 3, wybór i oprac. S. Wołoszyn, Kielce 1998, s. 10. 
są warte propagowania przy wykorzystaniu świadectw osobistych ich twórców. I nie tylko tych świadectw, które ukazały się drukiem, ale i tych, które znajdują się w archiwach. Prawdziwymi bowiem skarbnicami ego-dokumentów są archiwa, które kryją w swych zasobach niezwykłe bogactwo dowodów pamięci historycznej. Pamięć zaś jest zasadniczym elementem tego, co od niedawna nazywa się tożsamością indywidualną lub zbiorową ${ }^{61}$.

\section{Bibliografia}

Arendt H., Heidegger M., Korespondencja z lat 1925-1975, na podstawie spuścizny obojga autorów oprac. U. Ludz, przeł. S. Lisiceka, Warszawa 2010.

Barszczewska L., Milewicz B., Wspomnienia o Januszu Korczaku, Warszawa 1989.

Bojanowski E., Korespondencja Edmunda Bojanowskiego z lat 1829-1871, t. 1: Listy Edmunda Bojanowskiego z lat 1836-1871, objaśnił, skomentował i zarysem monograficznym poprzedził L. Smołka, Wrocław 2001.

Bojanowski E., Dziennik 1853-1871, wybór, wstęp i przypisy A. i T. Szafrańscy, Warszawa 1988.

Chałasiński J., Pamiętnikarstwo jako świadectwo przeobrażeń narodu polskiego, w: Pamiętniki Polaków 1918-1978. Antologia pamiętnikarstwa polskiego, t. 1: Druga Rzeczpospolita 1918-1939, wstęp J. Chałasiński, J. Szczepański, wybór i oprac. B. Gołębiowski, M. Grad, F. Jakubczak, Warszawa 1982.

Chłędowski K., Galicyjskie wspomnienia szkolne, do druku przygot. A. Knot, Kraków 1955.

Chłędowski K., Pamiętniki, Galicja 1843-1880, t. 1, wstęp i przypisy A. Knot, Kraków 2006.

Chrzanowski I., Pigoń S., Mistrz i uczeń: korespondencja wzajemna (1914-1936), do druku przygot., wstępem i przypisami opatrzył Cz. Kłak, Rzeszów 2005.

Cieński A., Z dziejów pamiętników w Polsce, Opole 2002.

Czapliński W., Pamiętnik jako źródto dla historyka nowożytnego, „Pamiętnikarstwo Polskie” 1972 , nr 2.

Czermińska M., Autobiografia, Gdańsk 2009, t. 9, Archiwum przekładu „Pamiętnika Literackiego".

Czermińska M., Autobiograficzny trójkąt: świadectwo, wyznanie i wyzwanie, Kraków 2000.

Dąbrowska M., Dzienniki 1914-1945, wybór, wstęp i przypisy T. Drewnowski, Warszawa 1998.

${ }^{61}$ J. Le Goff, dz. cyt., s. 155. 
Demetrio D., Autobiografia. Terapeutyczny wymiar pisania o sobie, przeł. A. Skolimowska, przedmowa O. Czerniawska, Kraków 2000.

Dróżka W., Młode pokolenie nauczycieli. Studium autobiografii młodych nauczycieli polskich lat dziewięćdziesiąych, Kielce 1997.

Dróżka W., Nauczyciel, autobiografia pokolenia. Studia pedeutologiczne i pamiętnikarskie, Kielce 2002.

Falski M., Z okruchów wspomnień, oprac. i przypisy. M. Kossecka, wstęp A. Ossowska-Zwierzchwoska, Bydgoszcz 2007,

Gadamer H. G., Moja droga do filozofii. Wspomnienia, przeł. J. Wilk, Wrocław 2000.

Gadowski W., Wspomnienia katechety, red. A. Solak, Kraków 2002.

Gołębiowski B,. Pamiętnikarstwo i literatura. Szkice z socjologii kultury, Warszawa 1973.

Gomulicki W., Wspomnienia niebieskiego mundurka, Pułtusk 2007.

Górski K., Autobiografia naukowa, red. W. Sierdzan, Toruń 2003.

Górski K., Pamiętniki, Torun 1995.

Grzybowski S., Wspomnienia, Zakamycze 1999.

Gusdorf G., Warunki i ograniczenia autobiografii, w: Autobiografia, red. M. Czermińska, Gdańsk 2009.

Radlińska H., Kamiński A., Uziembło A. O., Listy o pedagogice społecznej, red. W. Theiss, Warszawa 1997.

Herbert Z., Elzenberg H., Korespondencja, Warszawa 2002.

Iłłakiewiczówna K., Ścieżka obok drogi, wyd. 2, Warszawa 1939.

Iwaszkiewicz J., Książka moich wspomnień, Poznań 2010.

Jakubczak F., Metodologiczne problemy użytkowania dokumentów pamiętnikarskich w badaniach nad kulturq współczesna, w: Ruch pamiętnikarski i przemiany polskiej kultury, red. B. Gołębiowski, J. Kossak, K. Krzemień, Warszawa 1972.

Jaspers K., Autobiografia filozoficzna, przeł. i przypisami opatrzył S. Tyrowicz, Toruń 1993.

Jędrzejewicz W., Wspomnienia, oprac. i posł. J. Cisek, Wrocław 1993.

Kalembka S., Urywki wspomnień, Toruń 2009.

Kolankowski L., Ludwik Kolankowski 1882-1956. Zapiski pamiętnikarskie, do druku przygot., wstępem i przypisami opatrzyła S. Grochowina, Toruń 2012.

Korczak J., Pamiętnik i inne pisma z getta, przypisy M. Ciesielska, posł. J. Leociak, Warszawa 2012. 


\section{METODY ZBIERANIA I ANALIZY DANYCH W BADANIACH EDUKACYJNYCH}

Kozakiewicz J., Pamiętniki jako źródła oraz ich funkcja w procesie kształtowania świadomości społecznej, „Historyka” 1982, t. 12.

Lam S., Życie wśród wielu, przygot. do druku A. Lam, Warszawa 1968.

Lanckorońska K ., Szkice wspomnień, przedmowa A. Biernacki, Warszawa 2005.

Lanckorońska K., Wspomnienia wojenne. 22 IX1939-5 IV 1945, słowo wstępne L. Kalinowski, E. Orman, Kraków 2003.

Le Goff J., Historia i pamięć, przeł. A. Gronowska, J. Stryjczyk, wstęp P. Rodak, Warszawa 2007.

Lejeune P., „,Drogi zeszycie...”, ,,drogi ekranie...”. O dziennikach osobistych, przeł. A. Karpowicz, M. Rodak, P. Rodak, wybór, wstęp i oprac. P. Rodak, Warszawa 2010.

Lejeune P., Wariacje na temat pewnego paktu. O autobiografii, red. R. Lubas-Bartoszyńska, przeł. W. Grajewski i in., Kraków 2001.

Łempicki S., Wspomnienia ossolińskie, Wrocław 2006.

Majorek C., Glosa do rozważań o historii wychowania, w: Źródła do dziejów wychowania i myśli pedagogicznej, t. 3, wybór i oprac. S. Wołoszyn, Kielce 1998.

Majorek C., Rola badań biograficznych w rekonstrukcji dziejów oświaty i pedagogiki w Galicji, w: Biografie pedagogiczne. Szkice do portretu galicyjskiej pedagogii, red. C. Majorek, J. Potoczny, t. 9: Galicja i jej dziedzictwo, Rzeszów 1997.

Maniakowska H., Leon Jeśmianowicz (1914-1989) we wspomnieniach wspótpracowników i przyjaciót, Toruń 2009.

Maternicki J., Pamiętnik jako dokument kultury historycznej, „Przegląd Humanistyczny” 1985, nr 11-12.

Maternicki J., Materiały autobiograficzne i ich funkcja poznawcza i dydaktyczna, w: J. Maternicki , Historia i wychowanie, Warszawa 1990.

Mckinley W. R., Historie życia a psychobiografia. Badania teorii i metody, przeł. J. Kasprzewski, Warszawa 1992.

Mysłakowski Z., Zatracone ścieżki, zagubione ślady, Warszawa 1967.

Okoń W., Samo życie osiemdziesięciolatka z autobiografia naukowa autora, Warszawa 2005.

Ratajczak J., Lekcje u Iłłakiewiczówny (szkice, wspomnienia, listy i wiersze), Poznań 1986.

Ricoeur P., Pamięć, historia, zapomnienie, przeł. J. Margański, Kraków 2006.

Ricoeur P., Refleksja dokonana. Autobiografia intelektualna, przeł. P. Bobowska-Nastarzewska, Kęty 2005.

Rousseau J. J., Wyznania, przeł. i wstępem opatrzył T. Żeleński (Boy), Warszawa 1956. 
Schülze W., Ego-Dokumente. Annäherung an den Menschen in der Geschichte (Selbstzeugnisse der Neuzei t. 2), w: Ego-Dokumente. Annäherung an den Menschen in der Geschichte, red. W. Schülze, Berlin 1996.

Serczyk J., Minęło życie, Toruń 1999.

Skarga B., Po wyzwoleniu... 1944-1956, Poznań 1990.

Skwarek I., Dlaczego autobiografizm? Powieści autobiograficzne dwudziestolecia międzywojennego, Katowice 1986.

Szulakiewicz W., „Lwów dziennikarski” we wspomnieniach Stanisława Łempickiego, w: Orientacje i kierunki $w$ badaniach historyczno-pedagogicznych, red. I. Michalska i G. Michalski, Łódź 2009.

Szulakiewicz W., Biografistyka i jej miejsce w historiografii edukacyjnej po II wojnie światowej, „Biuletyn Historii Wychowania” 2004.

Szulakiewicz W., Biografistyka w polskiej historiografii edukacyjnej, w: Powiazania rodzinne wśród twórców polskiej teorii i praktyki, red. W. Jamrożek, K. Kabacińska, K Ratajczak, Poznań 2007.

Szulakiewicz W., Dziedzictwo naukowe Uniwersytetu Jagiellońskiego i Uniwersytetu Lwowskiego okresu autonomii galicyjskiej. Mistrzowie i seminaria naukowe, Artes Liberales, „Zeszyty Naukowe Akademii Humanistycznej im A. Gieysztora” 2007, nr 2.

Szulakiewicz W., O uczacych i uczonych. Szkic z pedeutologii historycznej, w: Wdzięczność i zobowiązanie. Myśl Jana Pawła II źródłem inspiracji współczesnego środowiska akademickiego, red. Cz. Kustra, Torun 2009.

Szulakiewicz W., Opowiadając o sobie. Obraz dzieciństwa we wspomnieniach wybitnych ludzi (w druku).

Szulakiewicz W., Pamiętnikarski portret nauczycieli w ujęciu Rafała Taubenschlaga (1881-1958), w: Z dziejów polskiej oświaty. Księga Jubileuszowa dedykowana Profesor Danucie Koźmian, red. I. Kość i E. Magiera, Szczecin 2007.

Szulakiewicz W., Rola literatury pamiętnikarskiej w rekonstrukcji obrazu galicyjskiego szkolnictwa. Z pamiętnika Rafała Taubenschlaga, w: Galicja i jej dziedzictwo, red. K. Szmyd, J. Dybiec, t. 20: Historia wychowania. Misja i edukacja, Rzeszów 2008.

Tatarkiewicz T., Tatarkiewicz W., Wspomnienia, Poznań 2011.

Theiss W., Listy o pedagogice społecznej, Helena Radlinska, Aleksander Kamiński, Adam O. Uziembło, Warszawa 1997.

Tomasik E., Marii Grzegorzewskiej listy do przyjaciót, Warszawa 2002.

Tomaszewski T., Pejzaż psychologiczny, Warszawa 1996.

Tomczak A., Uniwersytet Mikołaja Kopernika. Wspomnienia pracowników, Toruń 1995. 
Trzynadlowski J., Struktura relacji pamiętnikarskiej, w: Księga pamiątkowa ku czci Stanisława Pigonia, red. Z. Czerny i in., Kraków 1961.

Twardowski K., Dzienniki, t. 1-2, Warszawa-Toruń 1997.

Tyrowicz M., W poszukiwaniu siebie. Wspomnienia i refleksje, t. 1: Pod lwowskim niebem, Lublin 1988.

Wajsblum M., Kot S., „Zawsze bytem Żydem dla Polaków i Polakiem dla Żydów”. Listy Marka Wajsbluma do Stanisława Kota z lat 1927-1961, oprac. i wstępem opatrzyli Z. Pietrzyk i Z. Koziński, Kraków 1996.

Walczyk I., Streich W., Uniwersytet Mikołaja Kopernika. Wspomnienia absolwentów, Toruń 2009.

Zamoyska J., Wspomnienia, Londyn 1961.

Ziółek J., Katolicki Uniwersytet Lubelski w latach 1944-1952. Wspomnienia i relacje, Lublin 1999.

Żmichrowska N., Baranowska J. Ścieżki przez życie. Wspomnienia, oprac. M. Romankówna, wstęp Z. Kossak, Wrocław 2006.

Żygulski K., Jestem z lwowskiego etapu..., Warszawa 1994.

\section{Ego-documents and their role in scientific studies}

\section{Summary}

The article tries to demonstrate the significant role of ego-documents in scientific studies.

The article presents their characteristics and indicates their biographical nature. In addition to that, it also describes reasons behind the distorting of historical truth, contained in memoirs. Thanks to the examples presenting the use of various memoir-based sources in scientific studies, it was possible to emphasize their significance in reconstructing the history of pedagogy, education and learning. 